\title{
Thermostability of Doubly Glycosylated Recombinant Lysozyme
}

\author{
Yoshio Hashimoto, Osamu Munemura, Kiyonari Masumoto, Tadashi UedA, and Taiji Iмото* \\ Graduate School of Pharmaceutical Sciences, Kyushu University, 3-1-1 Maidashi, Higashi-ku, Fukuoka 812-8582, Japan. \\ Received March 13, 2001; accepted June 22, 2001
}

\begin{abstract}
We prepared a lysozyme mutant (Q41S/R61S) introducing Asn-type glycosylation signal sites by yeast expression system. On purification by cation exchange column at $\mathrm{pH} 7$, three fractions were obtained. Peptide mapping and mass-spectrometry showed the fractions were the derivatives glycosylated at both Asn39 and Asn59, at only Asn39, and not glycosylated. It was revealed that the processing of Asn-linked oligosaccharide at Asn39 and Asn59 occurred independently in yeast cells. The denaturation temperatures of these derivatives by differential scanning calorimetry were $76.0,68.8$, and $67.5^{\circ} \mathrm{C}$ at $\mathrm{pH} 3$, respectively. The stabilization of glycosylated lysozyme depends on the degree of glycosylation. We concluded that stabilized proteins can be constructed by glycosylation at proper sites. Thermodynamic stabilization by the artificial double glycosylations on a protein has not yet been reported.
\end{abstract}

Key words Asn-type glycosylation; denaturation temperature; lysozyme; protein stability

Proteins containing covalently bonded oligosaccharidechains are widely distributed in cells. The oligosaccharidechains are called the third biological chain after nucleic acids and proteins and have more diverse function than nucleic acids or proteins. This diversity decides the function, characterization and distribution of glycoproteins. The diversity is attributable to the absence of template in the biosynthesis, though DNA replication, mRNA transcription, or protein translation is carried out in the presence of the template. Oligosaccharide-chains of glycoproteins are related to the retention of active structure, extension of retention time within the body, selective transport of proteins in cells, signal transduction, cell adhesion, differentiation of cell, control of cell proliferation, etc. ${ }^{1,2)}$

There is, however, little information on the addition site of the oligosaccharide-chain, compared to information on the chain itself. In spite of the presence of the Asn-type glycosylation signal sequence, Asn-Xaa-Ser/Thr (Xaa: any amino acids except proline), non-glycosylated protein is present. ${ }^{3,4)}$ On the other hand, when the glycosylation signal sequence was introduced into non-glycosylated protein by gene engineering, glycosylation was confirmed and the glycosylated protein was analyzed ${ }^{5,6)}$ Proper selection and combination of the glycosylated positions enables us to prepare highly stable proteins. Thermodynamic stabilization by artificial double glycosylation on a protein has not yet been reported.

In this report, we selected hen lysozyme as a model protein and prepared two single mutants, Q41S and R61S, which are mutant lysozymes in which Gln-41 and Arg-61 were substituted with Ser, respectively (Fig. 1). We previously screened the proper sites to introduce glycosylation on the basis of each asparagine residue in lysozyme (unpublished data). As a result, Q41S and R61S were glycosylated and thermodynamically more stable than the wild type. Thus, the double mutant Q41S/R61S, into which the double glycosylation can be introduced, was prepared and characterized.

\section{MATERIALS AND METHODS}

Materials Polymerase chain reaction (PCR) was carried out with an "Expand High Fidelity PCR System" (EHF) kit from Roche (Germany). T4 DNA ligase and restriction enzymes were from Fermentas MBI (Lithuania). Oligonucleotides were synthesized by Life Technologies, Inc. (MD, U.S.A.). Micrococcus luteus (M. luteus), a substrate of lysozyme, was purchased from Seikagaku Kogyo (Tokyo, Japan), and CM-Toyopearl $650 \mathrm{M}$, a cation-exchange resin, was from Tosoh (Tokyo). $N$-tosyl-L-phenylalanyl chloromethyl ketone (TPCK)-trypsin was from Sigma Chemicals (St. Louis, U.S.A.).

Site-Directed Mutagenesis and Construction of Yeast Expression Vectors for Q41S and R61S Mutants Lysozyme mutant genes, Q41S and R61S, were prepared as reported $^{7}$ with a slight modification in the PCR method. A thermal cycler used for PCR was the "Mini Cycler" (MJ Research). The first PCR (10 cycles of $45 \mathrm{~s}$ at $95^{\circ} \mathrm{C}, 1 \mathrm{~min}$ at $50^{\circ} \mathrm{C}$ and $1 \mathrm{~min}$ at $72^{\circ} \mathrm{C}$, followed by 15 cycles of $45 \mathrm{~s}$ at $95^{\circ} \mathrm{C}, 1 \mathrm{~min}$ at $50^{\circ} \mathrm{C}$, and $1 \mathrm{~min}$ at $72^{\circ} \mathrm{C}$ with extension of $20 \mathrm{~s}$ per cycle) was carried out. The reaction was carried out under the condition of $15 \mathrm{pmol}$ of a mutagenic oligonucleotide (LZ-246 or LZ-249), $12.5 \mathrm{pmol}$ of 3 '-flanking primer (LZ-166), $5 \mu \mathrm{l}$ of $10 \times$ EHF buffer, $200 \mu \mathrm{M}$ of a mixture of dATP, dCTP, dGTP and dTTP (dNTP), $7 \times 10^{-17} \mathrm{~mol}$ of a template of lysozyme cDNA in vector pNKSUC (Hashimoto et al., 1998a), and 2.6 U polymerase of EHF kit, in a total reaction volume of $50 \mu$. The second PCR was car-

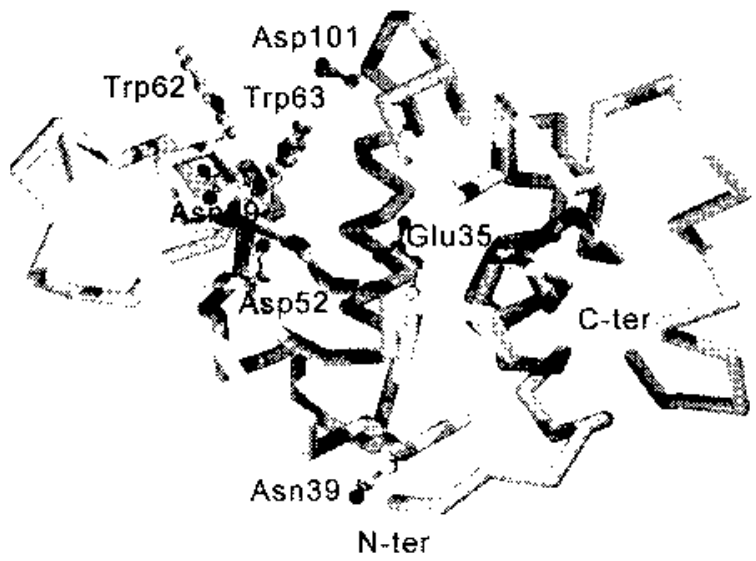

Fig. 1. Structure of Lysozyme and the Sites of Asn39 and Asn59

Glu35 and Asp52 are the catalytic residues and Trp62, Trp63, and Asp101 are important residues associated with the substrate-binding. 
ried out in the tube of the first PCR with additional reagents: $15 \mathrm{pmol}$ of $5^{\prime}$-flanking primer (LZ-167), $5 \mu \mathrm{l}$ of $10 \times \mathrm{EHF}$ buffer, $200 \mu \mathrm{M} \mathrm{dNTP}$ and $2.6 \mathrm{U}$ polymerase of EHF kit, in a total reaction volume of $100 \mu \mathrm{l}$. Nucleotide sequences of LZ166, LZ-167, LZ-246 and LZ-249 were 5'-GGCGGTCGACGTATATGATGCTTTTGCAAG-3'， 5'-GGCGGATCCTCACAGCCGGCAGCCT-3', 5'-CTTCAACACCTCTGCTACAAACC-3' and 5'-GATCAACAGCTCCTGGTGGTG-3', respectively. Q41S and R61S mutant genes were digested with both SalI and BamHI, and ligated to yeast expression vector, pHA394. ${ }^{8)}$ Escherichia coli (E. coli) RR1 was transformed with the ligation mixture. The nucleotide sequence of Q41S mutant gene was confirmed by DNA sequencing (DNA sequencer 377A, PE-ABI). Expression vectors for Q41S and R61S mutants were termed pYMU-Q41S and pYMU-R61S, respectively.

Site-Directed Mutagenesis and Construction of Yeast Expression Vector for Q41S/R61S Double Mutant Lysozyme mutant (Q41S/R61S) gene was prepared as a template of pYMU-Q41S. The first PCR was carried out using two primers LZ-166 and LZ-249, followed by a second PCR using a primer LZ-167 and the first PCR product. Q41S/ R61S mutant gene was digested with both Sal I and BamHI, and ligated to yeast expression vector, pHA394 (Hashimoto et al., 1998b). E. coli RR1 was transformed with the ligation mixture. Nucleotide sequence of Q41S/R61S mutant gene was confirmed by DNA sequencing. The expression vector for Q41S/R61S mutant was termed pYMU-Q41S/R61S.

Yeast Manipulation Yeast Saccharomyces cerevisiae $(S$. cerevisiae) AH22 was transformed by expression plasmids, pYMU-Q41S, pYMU-R61S, and pYMU-Q41S/R61S according to the spheroplast method.9 ${ }^{9}$ Since yeast AH22 requires histidine and leucine, and pHA394 contains the leu 2 gene, yeast transformants harboring pHA394 derivatives were selected on a modified Burkholder minimal medium plate containing only histidine as an amino acid. ${ }^{10)}$

Expression, Secretion and Purification of Lysozyme Mutant with Yeast Yeast was cultivated and lysozymes were purified as previously described. ${ }^{11)}$ Yeast cells were grown in a modified Burkholder minimal medium ${ }^{12)}$ supplemented with $8 \%$ sucrose, $5 \mathrm{~g} / 1$ asparagine, $100 \mathrm{mg} / 1$ histidine, $100 \mathrm{mg} / 1$ tryptophan and $0.6 \mathrm{~mm} \mathrm{KH}_{2} \mathrm{PO}_{4}$ (pH 5.3). Expression and secretion of lysozymes were carried out by growing a yeast transformant for $125 \mathrm{~h}$ in a modified Burkholder minimal medium at a low phosphate $\left(0.6 \mathrm{~mm} \mathrm{KH}_{2} \mathrm{PO}_{4}\right)$. The lysozyme secreted in the culture supernatant was isolated by cation-exchange chromatography on a column $(1.3 \times 40 \mathrm{~cm})$ of CM-Toyopearl 650M, which was eluted with a gradient of $200 \mathrm{ml}$ of $0.05 \mathrm{M}$ phosphate buffer and $200 \mathrm{ml}$ of the same buffer containing $0.5 \mathrm{M} \mathrm{NaCl}$ at $\mathrm{pH} 7$ and $4{ }^{\circ} \mathrm{C}$. The protein fractions on the chromatogram $(\mathrm{pH} \mathrm{7)}$ were collected, dialyzed against distilled water, and lyophilized. The lyophilized protein was then loaded on a cation-exchange chromatocolumn with a gradient of $200 \mathrm{ml}$ of $0.05 \mathrm{M}$ acetate buffer and $200 \mathrm{ml}$ of the same buffer containing $0.5 \mathrm{M} \mathrm{NaCl}$ at $\mathrm{pH} 5$ and $4{ }^{\circ} \mathrm{C}$. The protein fractions on the chromatogram $(\mathrm{pH} 5)$ were collected, dialyzed against distilled water, and lyophilized. ${ }^{11)}$

Construction of $E$. coli Expression Vector for Q41S/ R61S Mutant PCR was carried out as a template of pYMUQ41S/R61S using two primers, LZ-167 and LZ-188. The nucleotide sequence of LZ-188 is 5'-CGCAAGCTTCATATG-
TCTAAAGTCTTTGGACGATGTGAG-3' . PCR product was digested with both $N d e \mathrm{I}$ and $B a m \mathrm{HI}$, and ligated to an E. coli expression vector, pET22b(+) (Novagene). E. coli BL21 (DE3) was transformed with the ligation mixture.

Expression and Purification of Lysozyme Mutant with E. coli Q41S/R61S mutant was expressed according to the pET system manual from Novagene. Namely, isopropyl-1thio- $\beta$-D-galactoside (IPTG) was added at $1 \mathrm{~mm}$ to the culture medium after $\mathrm{OD}_{600}$ reached 0.6. The culture was shaken for $4 \mathrm{~h}$. Purification of lysozyme mutant was carried out by the method of Mine et al. ${ }^{12)}$ Cells were harvested by centrifugation for $10 \mathrm{~min}$ at $8000 \mathrm{rpm}$. Pellets were suspended in $30 \mathrm{ml}$

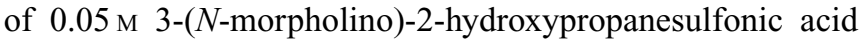
(MOPSO) ( $\mathrm{pH} \mathrm{7)}$ and then sonicated for $30 \mathrm{~s} 20$ times in an ice-water bath. The mixture was centrifuged for $30 \mathrm{~min}$ at $7000 \mathrm{rpm}$. The precipitates were suspended in $6 \mathrm{ml}$ of $6 \mathrm{M}$ guanidium hydrochloride $/ 0.575 \mathrm{M}$ Tris- $\mathrm{HCl} / 5.25 \mathrm{~mm}$ EDTA ( $\mathrm{pH} 8.6$ ) and reduced with $50 \mu \mathrm{l}$ of mercaptoethanol at $40{ }^{\circ} \mathrm{C}$ for $1 \mathrm{~h}$. The reduced mixture was diluted into $100 \mathrm{ml}$ of $10 \%$ acetic acid by dropwise addition and vigorous stirring to extract the reduced lysozyme mutant. The supernatants were lyophilized and loaded on a column $(1.5 \mathrm{~cm} \times 150 \mathrm{~cm})$ of Sephadex G-75 with 10\% acetic acid as eluent. The fractions were lyophilized to give fairly pure lysozyme mutant in an active form.

Sodium Dodecyl Sulfate-Polyacrylamide Gel Electrophoresis (SDS-PAGE) SDS-PAGE was conducted according to the method of Laemmli ${ }^{13)}$ using $15 \%$ acrylamide separating gel and 7.5\% stacking gel containing 1\% SDS. After electrophoresis, the gel sheets were stained using Coomassie Brilliant Blue R-250 (CBB) and periodic acid/Schiff (PAS) reagent. ${ }^{14)}$

Enzyme Assay Activity of lysozyme against $M$. luteus $(0.25 \mathrm{mg} / \mathrm{ml})$ was determined turbidimetrically at $450 \mathrm{~nm}$ in $0.05 \mathrm{M}$ potassium phosphate buffer at $\mathrm{pH} 7$ and $30^{\circ} \mathrm{C} .{ }^{15)}$

Peptide-Mapping Analysis Digestions of reduced and $S$-carboxymethylated lysozymes with TPCK-trypsin and separation of the resulting peptides on a reversed-phase HPLC were accomplished as described by Yamada et al. ${ }^{16)}$

Measurement of Molecular Weight of Peptides For MALDI TOF mass spectrometry, $1 \mu \mathrm{l}$ of the peptide solution was applied to a target disk and allowed to air-dry. Subsequently, $9 \mu \mathrm{l}$ of matrix solution ( $1 \% \mathrm{w} / \mathrm{v} \alpha$-cyano-4-hydroxycinnamic acid in $50 \%$ acetonitrile, $0.1 \% \mathrm{v} / \mathrm{v}$ trifluoroacetic acid) was applied to the dried sample and again allowed to dry. Spectra were obtained using a Voyager ELITE XL mass spectrometer (PE-PerSeptive Biosystems, Framingham, MA, U.S.A.).

Measurement of Denaturation Temperature of Lysozymes Denaturation temperatures of lysozyme derivatives were measured with a VP-DSC Micro Calorimeter (Micro Cal Inc.). Sample solutions $(10 \mu \mathrm{M})$ for this analysis were prepared by dissolving proteins in $0.05 \mathrm{M}$ glycine hydrochloride buffer ( $\mathrm{pH} \mathrm{2.4,} 2.6$ and 3.0), and the solutions were dialyzed against each buffer. The $\mathrm{pH}$ of the sample solution was confirmed both before and after the measurements.

\section{RESULTS}

Purification of Q41S, R61S and Q41S/R61S Mutants Lysozymes secreted in the yeast culture medium were puri- 
(a)

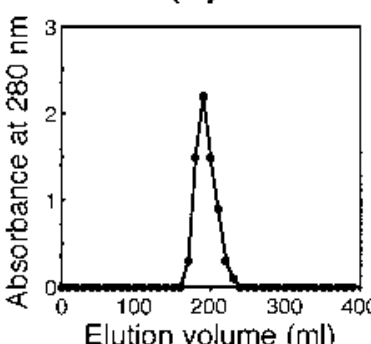

Elution wolume (ml) (b) (c)

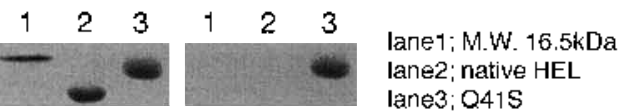

(B)

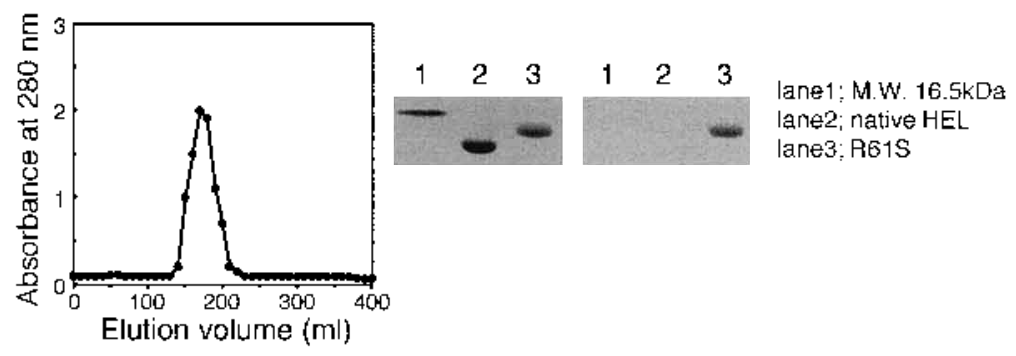

(C)

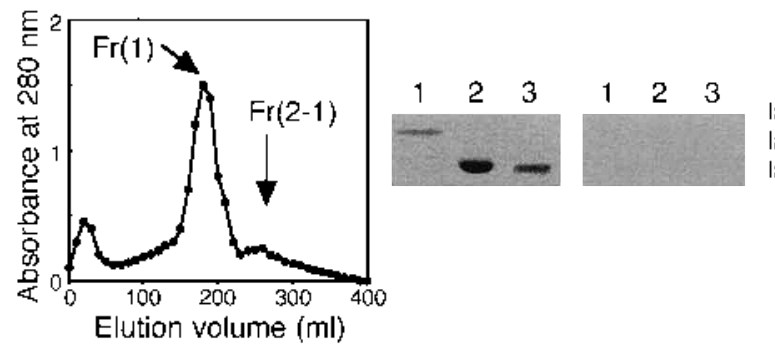

lane 1; M.W. 16.5kDa

lane2; native HEL

lane3; $F r(2-1) / Q 41 S / R 618$

(D)
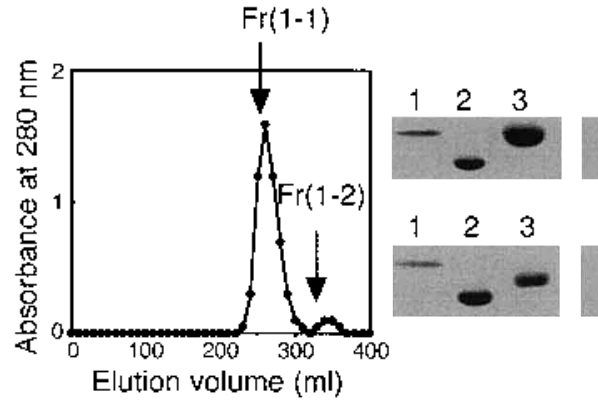

12

lanet; M.W. $16.5 \mathrm{kDa}$

lane2; native HEL

lane3; Fr(1-1)/G41S/R615

ane1: M W $16.5 \mathrm{kDa}$

lane2: native $\mathrm{HEL}$

lane3: $\operatorname{Fr}(1-2) / O 415 / R 615$

Fig. 2. Purification by Cation Exchange Chromatography and SDS-PAGE Profile of Q41S, R61S, and Q41S/R61S Mutants

(A) Chromatogram of Q41S mutant at $\mathrm{pH} 7$; (B) chromatogram of R61S mutant at $\mathrm{pH} 7$; (C) chromatogram of Q41S/R61S mutant at $\mathrm{pH} 7$; (D) chromatogram of Fr(1) at $\mathrm{pH}$, which is shown in profile (C); (a) cation exchange chromatogram; (b) staining profile with CBB after SDS-PAGE; (c) staining profile with PAS after SDS-PAGE.

fied by cation exchange chromatography (Fig. 2). Q41S and R61S mutants were singly separated at $\mathrm{pH}$ 7. These lysozyme fractions were further purified by a cation exchange column at $\mathrm{pH}$, resulting in a single peak (data not shown). On the other hand, Q41S/R61S mutant was purified by cation exchange chromatography at $\mathrm{pH} 7$, and gave two fractions, termed $\operatorname{Fr}(1)$ and $\operatorname{Fr}(2-1)$. $\operatorname{Fr}(1)$ was further purified by cation exchange chromatography at $\mathrm{pH}$. Two fractions were obtained, termed $\operatorname{Fr}(1-1)$ and $\operatorname{Fr}(1-2)$. The proteins purified by the cation exchange chromatography were analyzed by SDSPAGE, and stained with CBB and PAS to check for purity of protein and degree of glycosylation (Fig. 2). Purities of Q41S mutant, R61S mutant, $\operatorname{Fr}(1-1), \operatorname{Fr}(1-2)$, and $\operatorname{Fr}(2-1)$ were more than $95 \%$ on the SDS-PAGE, and secretion yields of these five lysozymes were $1.86,2.03,1.32,0.11$, and $0.12 \mathrm{mg}$ per liter. Q41S mutant, R61S mutant, $\operatorname{Fr}(1-1)$, and $\operatorname{Fr}(1-2)$ were glycosylated. Degree of glycosylation on $\operatorname{Fr}(1-1)$ was higher than that on $\operatorname{Fr}(1-2)$.

Tryptic Peptide-Mapping Analysis Peptide-mapping analysis was carried out to clarify whether oligosaccharide chains are attached on peptide(s) containing 41st or/and $61 \mathrm{st}$ residues (Figs. 3 and 4). Tryptic peptides of reduced and $S$ carboxymethylated lysozymes were separated on reversed phase HPLC. As to the wild type lysozyme, the tryptic peptide 34-45 (T7) containing Gln41, the peptide 46-61 (T8) containing Arg61, and the peptide 61-68 (T9) were eluted at the positions shown in Fig. 4A. The peptide T7 from Fr(21) was eluted at the same position as the wild type. Peptides $46-68(\mathrm{~T} 8+9)$ were detected as a new peak in $\operatorname{Fr}(2-1)$ (Fig. 4B). As a control non-glycosylated protein, we prepared the Q41S/R61S mutant with E. coli. The peptide mapping profile of this mutant was identical with that of $\operatorname{Fr}(2-1)$ (data not shown). Thus, $\operatorname{Fr}(2-1)$ was identified as a non-glycosylated lysozyme, as also estimated from Fig. 2. The peptides T7 

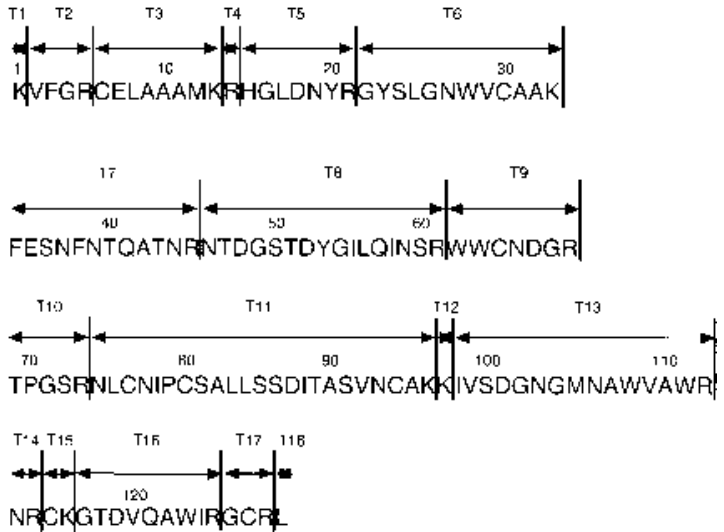

Fig. 3. Tryptic Peptide Sequence of Wild Type Lysozyme

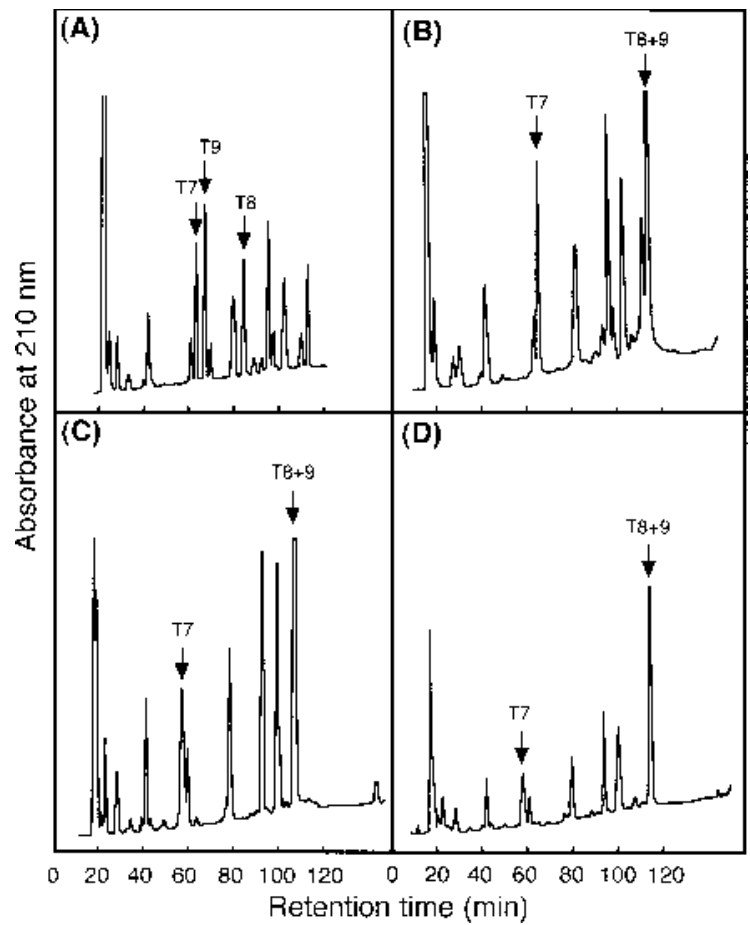

Fig. 4. Reversed Phase HPLC of Tryptic Peptides Obtained from Reduced and $S$-Carboxymethylated Lysozymes on a Column $(4 \times 250 \mathrm{~mm})$ of Wakopak 5C18

The column was eluted with a gradient formed from $50 \mathrm{ml}$ of $1 \%$ acetonitrile and $50 \mathrm{ml}$ of $50 \%$ acetonitrile, both containing $0.1 \%$ concentrated $\mathrm{HCl}$ at a flow rate of $0.6 \mathrm{ml}$ per minute. (A) Wild type; (B) $\operatorname{Fr}(2-1)$; (C) $\operatorname{Fr}(1-1)$; (D) $\operatorname{Fr}(1-2)$. T refers to the tryptic peptides and peptide numbering is from the $\mathrm{N}$-terminal peptide (Fig. 3 ).

from $\operatorname{Fr}(1-1)$ and $\operatorname{Fr}(1-2)$ were eluted faster than those from $\operatorname{Fr}(2-1)$ and were expected to be glycosylated. The peptide T8+9 from $\operatorname{Fr}(1-1)$ was eluted faster than that from $\operatorname{Fr}(2-1)$ and that from $\operatorname{Fr}(1-2)$ was eluted at the same position as that of $\operatorname{Fr}(2-1)$. These results showed that glycosylation would occur at both positions Asn39 and Asn59 on $\operatorname{Fr}(1-1)$ and at position Asn39 on $\operatorname{Fr}(1-2)$.

Molecular Weight Analyses of Tryptic Peptides Tryptic peptides separated by reversed phase HPLC were analyzed for molecular weight by MALDI-TOF mass spectrometry (Fig. 5). The theoretical molecular weight of peptides T7 and $\mathrm{T} 8+9$ on Q41S/R61S mutant is 1386 and 2680, respectively. T8+9 from Q41S/R61S mutant produced with E. coli, which are not glycosylated, were identical to the theoretical

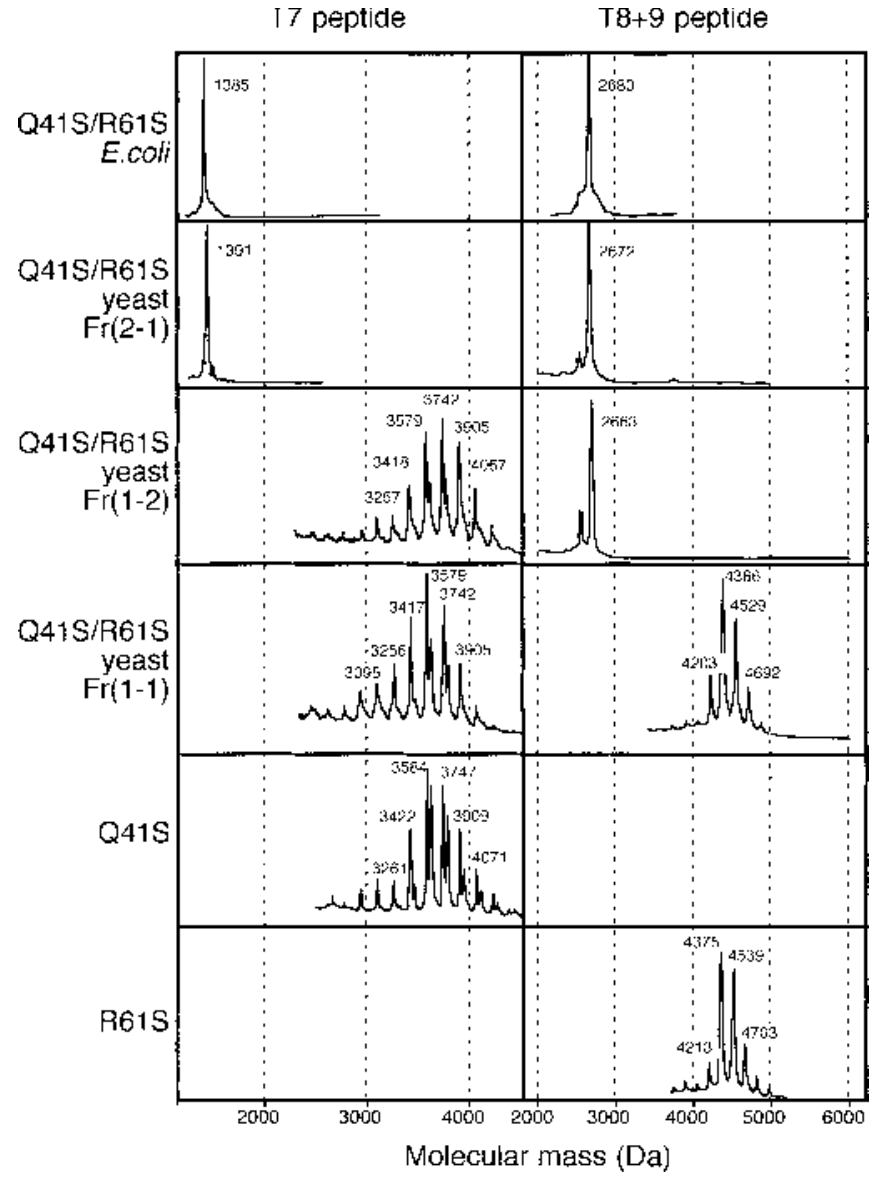

Fig. 5. MALDI-TOF Mass Spectrometric Analysis of the Tryptic Peptides from Lysozyme Derivatives

The tryptic peptides separated on reversed phase HPLC were analyzed for molecular weight by MALDI-TOF mass spectrometry. $\alpha$-Cyano-4-hydroxycinnamic acid was used as a matrix

values. The molecular weights of the peptides $\mathrm{T} 7$ and $\mathrm{T} 8+9$ of $\operatorname{Fr}(2-1)$ were also identical to the theoretical ones. This result shows that both peptides $\mathrm{T} 7$ and $\mathrm{T} 8+9$ of $\operatorname{Fr}(2-1)$ are not glycosylated, as expected from SDS-PAGE and peptide-mapping analyses (Figs. 2 and 4). The peptide T7 of $\operatorname{Fr}(1-2)$ was glycosylated, and consisted of heterogeneous molecular species, while the peptide $\mathrm{T} 8+9$ of $\operatorname{Fr}(1-2)$ was not glycosylated. Peptides T7 and T8+9 of $\operatorname{Fr}(1-1)$ were glycosylated. From these analyses, peptides $\mathrm{T} 7$ of $\operatorname{Fr}(1-2)$ and $\operatorname{Fr}(1-1)$ consist of two $N$-acetylglucosamines (NAG) and $8.8-12.4$ Dmannoses (Man), while peptide T8+9 of $\operatorname{Fr}(1-1)$ consists of two NAG and 6.1-8.8 Man. These glycosylated peptides were composed of some molecular species (Fig. 5), because the number of succharides attached were different.

Lytic Activities of Lysozymes For Q41S mutant, R61S mutant, $\operatorname{Fr}(1-1), \operatorname{Fr}(1-2)$, and $\operatorname{Fr}(2-1)$, lytic activities were measured at $\mathrm{pH} 7$ and $30^{\circ} \mathrm{C}$ (Fig. 6). Glycosylation of Asn39 did not seriously reduce the lytic activity (wild type $100 \% v s$. Q41S 76\%; Fr(2-1) 54\% vs. Fr(1-2) 42\%). Glycosylation of Asn59, however, seriously reduced the lytic activity (wild type $100 \%$ vs. R61S 4\%; $\operatorname{Fr}(1-2) 42 \%$ vs. $\operatorname{Fr}(1-1) 1 \%$ ).

Thermostabilities of Singly and Doubly Glycosylated Lysozymes Differential scanning calorimetry (DSC) analysis was carried out with a VP-DSC microcalorimeter at a scan rate of $1.0 \mathrm{~K} / \mathrm{min}$. The thermograms obtained for $\operatorname{Fr}(1-$ 1) and $\operatorname{Fr}(1-2)$ yielded two transitions (data not shown). 


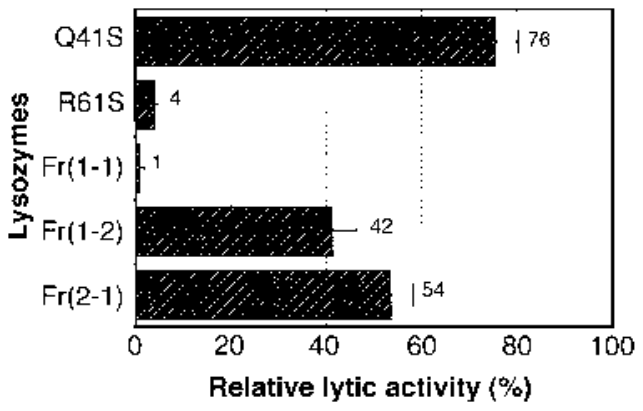

Fig. 6. Lytic Activity of Lysozyme Derivative

Relative activities are expressed by taking the activity of the wild type lysozyme at pH 7.0 and $30^{\circ} \mathrm{C}$ to be 100 .

Table 1. Denaturation Temperature of Lysozyme Derivatives

\begin{tabular}{lccc}
\hline \hline \multirow{2}{*}{ Mutant } & \multicolumn{3}{c}{ Denaturation temperature, Td $\left({ }^{\circ} \mathrm{C}\right)$} \\
\cline { 2 - 4 } & $\mathrm{pH} \mathrm{2.4}$ & $\mathrm{pH} \mathrm{2.6}$ & $\mathrm{pH} \mathrm{3.0}$ \\
\hline Wild type & 61.8 & 63.3 & 71.4 \\
Fr(1-1) & 68.7 & 69.0 & 76.0 \\
Fr(1-2) & 59.5 & 61.1 & 68.8 \\
Fr(2-1) & 58.5 & 60.0 & 67.5 \\
Q41S & 63.7 & 64.4 & 72.1 \\
R61S & 66.3 & 67.2 & 74.1 \\
\hline
\end{tabular}

Thus, the thermodynamic parameters were not analyzed. The denaturation temperatures (Td) of the main transitions of mutants were evaluated (Table 1). At $\mathrm{pH} 3.0$, Td of $\operatorname{Fr}(2-1)$, which was not glycosylated, was $67.5^{\circ} \mathrm{C}$, while that of wild type was $71.4^{\circ} \mathrm{C}$. Instability of $\operatorname{Fr}(2-1)$ compared to wild type would result from both Q41S and/or R61S mutations. Importantly, $\operatorname{Fr}(1-2)$ and $\operatorname{Fr}(1-1)$ were stabilized by $+1.3^{\circ} \mathrm{C}$ and $+8.5^{\circ} \mathrm{C}$ compared to $\operatorname{Fr}(2-1)$, respectively.

\section{DISCUSSION}

Three fractions were obtained from Q41S/R61S mutant: $\operatorname{Fr}(1-1), \operatorname{Fr}(1-2)$, and $\operatorname{Fr}(2-1) . \operatorname{Fr}(1-2)$ was glycosylated only at Asn39 position (Fig. 4). This result shows that the initial core glycosylation occurs in order from N-terminal to C-terminal in the course of translation. From the results of molecular weight analysis of tryptic peptides, the oligosaccharidetrimming profiles of position Asn39 on $\operatorname{Fr}(1-1)$ and $\operatorname{Fr}(1-2)$ were identical to that of Q41S single mutant. The profile of Asn59 on $\operatorname{Fr}(1-1)$ was also identical to that of R61S single mutant. Glycosylated lysozyme is expressed in small oligomannose- or large polymannose-chain forms. ${ }^{17)}$ The peptides T7 of $\operatorname{Fr}(1-2)$ and $\operatorname{Fr}(1-1)$ consist of two NAG and 8.8-12.4 Man, while peptide T $8+9$ of $\operatorname{Fr}(1-1)$ consists of two NAG and 6.1-8.8 Man. The diversity of mannose outer chains in yeast would be dependent on the characteristic of the protein structure, the degree of phosphorylation of the oligosaccharide-chains, the action of mannosyl transferase, etc. ${ }^{18,19)}$ In addition, the size of outer chains may also be determined by the time interval in which the corresponding proteins are present in the Golgi apparatus. These results show that the degree of trimming of the oligosaccharide-chain is different, depending on the individual and local environment: surface accessibility of Asn residue, local conformation, protein- folding state, etc.

The thermograms obtained for $\operatorname{Fr}(1-1)$ and $\operatorname{Fr}(1-2)$ yielded two transitions (data not shown). This is not because lysozyme has two domain structures since wild type lysozyme has a single thermotransition on DSC. ${ }^{20)}$ Glycosylated lysozymes, in contrast, had a minor transition on DSC, and IgGFc, which is glycosylated, has two transitions on DSC. ${ }^{21}$ Therefore, these two transitions may be because $\operatorname{Fr}(1-1)$ and $\operatorname{Fr}(1-2)$ consist of saccharides and protein. Thus, the thermodynamic parameters of the glycosylated lysozyme mutants were not calculated. $\operatorname{Fr}(1-2)$ and $\operatorname{Fr}(1-1)$ were stabilized by $+1.3 \mathrm{C}$ and $+8.5^{\circ} \mathrm{C}$ on $\mathrm{Td}$ compared to $\operatorname{Fr}(2-1)$ at $\mathrm{pH} 3.0$, respectively. Also, structures of glycosylated derivatives would not greatly change because Td's did not greatly change (Table 1). Therefore, stabilization of these glycosylated lysozymes depends on whether the glycosylation occurs or not at one/two sites. The stabilization of a protein by oligosaccharide chain can be explained in terms of "preferential hydration," which might affect the unfolded state of a protein more than the folded state. The term "preferential hydration" indicates that waters are compressed on a protein surface with the help of reagent. ${ }^{22)}$ Difference of activity between $\operatorname{Fr}(2-1)$ and $\operatorname{Fr}(1-2)$ shows the positional effect of glycosylation on activity. The glycosylation on Asn39 did not affect the activity very much because the position of Asp39 is apart from the active site. The glycosylation on Asn59, on the other hand, affected it seriously. We can consider two reasons for the decrease in activity by Asn59 mutation. 1) Sidechain of Asn59 is hydrogen-bonded to that of Asn46. Asn46 is one of the residues forming the substrate-binding cleft. ${ }^{23}$ ) The oligosaccharide-chain attached to Asn59 would block the formation of the substrate-binding cleft resulting in serious decrease in lytic activity. 2) The oligosaccharide-chain on Asn59 would hinder substrate from binding to lysozyme. Secretory proteins are often glycosylated, while no lysozymes are glycosylated in spite of secretory protein. Lysozymes would not be evolutionally glycosylated, because they are glycosidase. Since the binding of lysozyme to mannose moiety is not reported, we did not investigate the interaction between the oligosaccharide-chain and lysozyme in this study.

When the proper glycosylation site is selected, proteins is expected to be stabilized. There are various methods of stabilizing proteins ${ }^{24)}$ : introduction of a disulfide bond ${ }^{25,26)}$ or a proline residue, ${ }^{27)}$ removal of a glycine residue, ${ }^{27,28)}$ glycosylation of a protein, ${ }^{6,17)}$ etc. However, we do not always obtain the results we expect. A combination of stabilization factors would enable us to prepare highly stable proteins. ${ }^{24)}$ Additivities for mutational stability, enzymatic activity, enzyme-substrate interaction, and protein-protein interaction have been reported. $^{29-31)}$ Especially, Wells (1990) reviewed additivities of protein stability achieved by various point mutations in detail. $^{31)}$ Additivities of stabilization by artificial glycosylation have not yet been reported. To discuss the additivity, we attempted to calculate the thermodynamic parameters $(\Delta H$, $\Delta S$, and $\Delta G$ ). However, these parameters were not analyzed because the thermograms obtained yielded two transitions. In the present study, we showed that highly stabilized protein can be designed when multiple glycosylations and other mutations are combined. We would like to achieve protein stabilization and activity retention at the same time. However, we 
sacrificed the activity for the stabilization in this study. Selection of site for the sugar chain to be introduced is a matter for the future.

\section{REFERENCES}

1) Varki A., Glycobiology, 3, 97-130 (1993).

2) Varki A., Cummings R., Freeze H., Hart G., Marth J. (eds.), "Essentials of Glycobiology," Cold Spring Harbor Laboratory Press, New York, 1999.

3) Marshall R. D., Annu. Rev. Biochem., 41, 673-702 (1972).

4) Gavel Y., Heijne G., Protein Eng., 3, 433- 442 (1990).

5) Kato A., Nakamura S., Ban M., Azakami H., Yutani K., Biochim. Biophys. Acta, 1481, 88-96 (2000).

6) Ueda T., Iwashita H., Hashimoto Y., Imoto T., J. Biochem. (Tokyo), 119, 157-161 (1996).

7) Perrin S., Gilliland G., Nucleic Acids Res., 18, 7433-7438 (1990).

8) Hashimoto Y., Koyabu N., Imoto T., Protein Eng., 11, 75-77 (1998).

9) Hinnen A., Hicks J. B., Fink G. R., Proc. Natl. Acad. Sci. U.S.A., 75, 1929-1933 (1978)

10) Toh-e A., Ueda Y., Kakimoto S.-I., Oshima Y., J. Bacteriol., 113, 727-738 (1973).

11) Hashimoto Y., Yamada K., Motoshima H., Omura T., Yamada H., Yasukochi T., Miki T., Ueda T., Imoto T., J. Biochem., 119, 145-150 (1996).

12) Mine S., Ueda T., Hashimoto Y., Imoto T., Protein Eng., 10, 13331338 (1997).

13) Laemmli U. K., Nature (London), 227, 680-685 (1970).

14) Zacharius R. M., Zell T. E., Morrison J. H., Woodlock J. J., Anal. Biochem., 30, 148-152 (1969).
15) Verhamme I. M., Van D. G., Lauwers A. R., Eur. J. Biochem., 172, 615-620 (1988).

16) Yamada H., Ueda T., Kuroki R., Fukumura T., Yasukochi T., Hirabayashi T., Fujita K., Imoto T., Biochemistry, 24, 7953-7959 (1985).

17) Nakamura S., Takasaki H., Kobayashi K., Kato A., J. Biol. Chem., 268, 12706-12712 (1993).

18) Ballou C. E., Raschke W. C., Science, 184, 127-134 (1974).

19) Ballou C. E., Methods Enzymol., 185, $440-470$ (1990).

20) Ueda T., Masumoto K., Ishibashi R., So T., Imoto T., Protein Eng., 13, 193-196 (2000).

21) Ghirlando R., Lund J., Goodall M., Jefferis R., Immunol. Lett., 68, $47-52$ (1999).

22) Arakawa T., Bhat R., Timasheff S. N., Biochemistry, 29, 1924-1931 (1990).

23) Inoue M., Yamada H., Yasukochi T., Miki T., Horiuchi T., Imoto T., Biochemistry, 31, 10322-10330 (1992).

24) Imoto T., Cell Mol. Life Sci. (Experimentia), 53, 215-223 (1997).

25) Matsumura M., Becktel W. J., Levitt M., Matthews B. W., Proc. Natl. Acad. Sci. U.S.A., 86, 6562-6566 (1989).

26) Betz S. E., Protein Sci., 2, 1551-1558 (1993).

27) Hardy F., Vriend G., Veltman O. R., Van der Vinne B., Venema G., Eijsink V. G. H., FEBS Lett., 317, 89—92 (1993).

28) Margarit I., Campagnoli S., Frigerio F., Grandi G., De Filippis V., Fontana A., Protein Eng., 5, 543-550 (1992).

29) Gregoret L. M., Sauer R. T., Proc. Natl. Acad. Sci. U.S.A., 90, 42464250 (1993)

30) Hashimoto Y., Tokuyama K., Ito Y., Imoto T., Protein and Peptide Lett., 4, 265-270 (1997).

31) Wells J. A., Biochemistry, 29, 8509-8517 (1990). 